University of Pennsylvania Carey Law School

Penn Law: Legal Scholarship Repository

Faculty Scholarship at Penn Law

1980

\title{
The Labor Market and Illegal Immigration: The Outlook for the 1980s
}

Michael L. Wachter

University of Pennsylvania Carey Law School

Follow this and additional works at: https://scholarship.law.upenn.edu/faculty_scholarship

Part of the Immigration Law Commons, Labor and Employment Law Commons, Labor Economics Commons, Law and Economics Commons, Policy Design, Analysis, and Evaluation Commons, and the Political Economy Commons

\section{Repository Citation}

Wachter, Michael L., "The Labor Market and Illegal Immigration: The Outlook for the 1980s" (1980). Faculty Scholarship at Penn Law. 1359.

https://scholarship.law.upenn.edu/faculty_scholarship/1359

This Article is brought to you for free and open access by Penn Law: Legal Scholarship Repository. It has been accepted for inclusion in Faculty Scholarship at Penn Law by an authorized administrator of Penn Law: Legal Scholarship Repository. For more information, please contact PennlawIR@law.upenn.edu. 


\title{
THE LABOR MARKET AND ILLEGAL IMMIGRATION: THE OUTLOOK FOR THE 1980s
}

\author{
MICHAEL L. WACHTER*
}

\begin{abstract}
This paper first develops a labor supply forecast for the U.S. labor market in the 1980s, focusing on the effects of the low fertility rates of recent years. and then compares that forecast with the BLS projection of employment demand in the next decade. The author attempts to isolate those occupations and age-sex groups that are likely to have a shortfall of workers and to match the characteristics of those shortage categories with the demographic characteristics of the illegal alien work force. He predicts a relative shortage of unskilled workers in the $1980 \mathrm{~s}$, a major departure from past trends, and suggests that an increased flow of immigrants to meet that shortage would benefit skilled older workers and, to a lesser extent, the owners of capital He also argues, however, that increased immigration would harm domestic unskilled workers-who are increasingly minority group members-by lowering their relative income and raising their equilibrium unemployment rates.
\end{abstract}

$\mathrm{T}$ HE purpose of this paper is to investigate the outlook for the United States labor market in the 1980s in terms of its implications for immigration policy. The basic technical element in the study is a labor supply forecast that focuses on the likely impact of the forthcoming demographic twistthe changeover in the younger age groups from the oversized baby boom cohort to the undersized baby bust cohor (that is, the cohort born during the late 1960s and 1970s when fertility rates were very low). This important development on the supply side of the labor market is compared with the Bureau of Labor Statistics projections for occupational employment to 1985 .

- Michael Wachter is a professor of economics at the University of Pennsvlvania. The research for this paper was supported by grants from the General Electric Foundation and the National Institutes of Child Health and Human Development. Excellent research assistance was provided by William Wascher.
This study attempts to isolate those occupations and age-sex groups that are likely to have a shortfall of workers and to match the characteristics of the shortage categories with the demographic characteristics of the illegal alien work force. The results indicate an important reversal from usuat patterns. If performed for past decades, this analysis would have yielded projections indicating a surplus of unskilled workers; the calculations now indicate a relative shortage of unskilled workers over the next decade.

There are several ways this projected gap might be filled. The market mechanism, if left alone, would be expected to alter the relative prices and wages of different skill groups and capital so as to reduce the supply and demand gap. Relatively large discrepancies, however, would make necessary Iarge changes in relative wages and prices. To the extent that the market adjustments are politically painful, society may seek 
other models of adjustment. Legalizing and attempting to control the level of immigration is one such method.

This study suggests that in the $1980 \mathrm{~s}$, as the rate of increase in the native labor force declines, an increased flow of immigrants would benefit skilled older workers and, to a lesser extent, the owners of capital. More specifically, it would benefit the baby boom cohort as that group enters the thirty-andover age categories in the 1980 s, by allowing an increase in relative incone levels and occupational attainment of that cohort. If immigration flows were reduced in the 1980s, however, their position would decline further.

Whereas skilled workers would benefit from increased immigration, unskilled workers would be likely to find their relative income lowered and their equilibrium unemployment rates raised. This economic trade-off between illegal immigrants and the unskilled-especially the disadvantaged work force-seems unavoidable. The domestic unskilled labor supply in the 1980 s will be increasingly dominated, moreover. by minority workers. As a result, the tradeoff between accepting more immigrant workers and improving the economic position of the domestic disadvantaged population is likely to become a critical public policy issue.

\section{Labor Supply}

The forecast of the potential role of illegal aliens in the United States labor market of the 1980s is based on comparing labor supply and demand projections for that period. The labor supply can be broken down into four components: population, labor-force participation rates, hours of work, and immigration. Of the three domestic basic components, future changes in participation rates is the key variable in determining the labor supply in the 1980s.

The size of the working-age population over the next decade is known with some reliability, with future changes in birth rates not affecting the working-age population until at least the year 1995. The hours-ofwork component presents somewhat greater problems and, unfortunately, only limited work has been done on its projection.' Since hours have been relatively constant over the postwar period, I shall assume for simplicity that they will remain constant over the next decade. The primary concern with this assumption is the potential for shifts between full-and part-time work among the young people who are disproportionately represented in the lower skilled labor markets. In addition, I shall assume that legal and iIlegal immigration flows remain constant at existing levels in constructing the basic labor-supply projections. This assumption is useful because my analysis is focused on the effects of immigration. Immigration flows can then be vicwed as a policy variable dealing with imbalances that may develop in the labor market.

The labor-force participation equations utilized in this paper are updated versions of those published in one of my earlier studies. ${ }^{2}$ Calculations are made for the fourteen standard BLS age-sex groups using annual data. ${ }^{3}$ Due to a lack of space, those equations will not be summarized here (but they are available on request). They differ from the standard participation equations by the inclusion of cohort-related variables. Iraditional equations only capture age-specific effects (e.g., youths always have higher unemployment rates than older workers) and ignore cohort effects (e.g., youths in the baby boom cohore will do worse than youths in the baby bust cohort).

The major cohort variable is the percent-

${ }^{1}$ For a discussion of the hours-ot-work problem, see National Commission for Mitnpower Policy, Work Time and Employment, Special Report No. 28 (Washington: NCMP, October 1978).

2Michael L. Wachter. "Intermediate Swings in Labor-Force Participation Rates," Brookings Papers on Economic Activity, No. 2 (Washington, D.C.: The Brookings Institution. 1977), pp. 545-74.

It is not possible to obtain reliable regional breakdowns for the various age-sex groups. Since illegal immigrants are concentrated geographically, disag. gregation by region would be vatuable to test for regional effects. The limited empirical evidence that exists to date, however, does not isolate a large regional effect. This suggests that geographic mobility is sulficiently great for both the native and illegal immigrant populations for the assumption of a national labor market to be reasonable. Ste, for example, Waltet Fogel, Mexican Illegal Workers in the United States (Los Angeles: Institute of Industral Relations, University of California, 1977). 
age of persons age 16 to 34 relative to the total population age 16 and over. "This variable measures the effects of the relative size of the younger cohort on labor-force behayior. The economic assumption underlying this sariable, of crurse, is that the various age-sex groups atre imperfect substitutes for one another, Young workers and new entoints into the labor market lack specific training and, therefore, cannot compete effectively with prime-atge males who have acquired training due to their ongoing labor market attachment. An imbalance of inexperienced workers, caused by the entry of the baby boom cohort into the labor force, results in an increase in the relative unemployment rate and a decrease in the relative income of the younger workers. ${ }^{\text {Therefore, }}$ a surfeit of young workers (as is the case today) results in adverse labor market conditions for these groups. The result is an increase in the participation rate, especially of females, to compensate for the reduction in the income of the younger prime-age male workers.

The data support the relative cohort size variable as.a determinant of behavior. For example, since 1960 the sharp increase in female participation rates is heavily concentrated in the younger age group. These are the groups that have experienced a decline in their relative income position. Older females, with rising relative family income since 1960, have only slightly increased their participation rates over the past two decades.

The labor supply forecast is dependent, of course, upon the assumed values for the explanatory variables. The luture movements of two key variables are known. The trend variable increases along its predetermined rate of growth and the level of the cohort variable is given by the official U.S. popula-

'For a detailed discussion of this argument, sce' Michael L. Wacher, "The Demographic Impact on Unemployment: Past Experience and the Outlook for the Future," Demographic Trends unet Full Emplov. ment, National Commission for Manpower Policy. Special Report No. 12 (Washington: NCMP, December 1976), pp. 27-99. For empirical estimates of clisticities of substitution, sec Daniel S. Hanermesh and James Grant, "Econometric Surlies of Labor-Labor Substitution and Their Implications for Policy," mineo. Michigan Stare University, 1978. tion projections. For the rematning vari. ables, I have assumed the following: (1) un. employment remains at its equilibrium level over the entire period; (2) school en. rollment rates recover from their curren low levels and return close to their previous peak rates; (3) the armed forces remain a con. stant perecntage of the population; and (4) the current birth rate increases to the ero population growth level in 1981 and re. mains constant thereafter.

The number of workers projected to be in the labor force in 1985 and 1990 is shown in Table 1. These figures are obtained by multiplying the predicted labor-force participa-

\section{Table 1. Actual and Project Levels for Civilian Labor Force. 1970 to 1990 .}

(in thousands)

\begin{tabular}{|c|c|c|c|c|}
\hline \multirow{2}{*}{$\begin{array}{l}\text { Sex } \\
\text { and } \\
\text { Age }\end{array}$} & \multicolumn{2}{|c|}{ Actual Lerels } & \multicolumn{2}{|c|}{ Propedeat Levels } \\
\hline & 1970 & $\overline{197}$ & 1985 & 1990 \\
\hline \multicolumn{5}{|l|}{ Male } \\
\hline $16-19$ & 1005 & 1487 & 4751 & $466=$ \\
\hline $20-21$ & 5709 & 7872 & 7952 & tis8: \\
\hline $25-34$ & 11311 & 14886 & 18130 & 18834 \\
\hline $35-44$ & 10464 & 10618 & $|128|$ & 16758 \\
\hline $4.5-54$ & 10418 & 10187 & $971 i$ & $1098:$ \\
\hline $55-64$ & 7124 & $70)+2$ & 7345 & 7172 \\
\hline $63+$ & 2164 & 1826 & 1720 & 158 \\
\hline Total & 51195 & 57418 & 63893 & $6+587$ \\
\hline \multicolumn{5}{|l|}{ Female } \\
\hline $16-19$ & 3241 & 1268 & 4.802 & $4+402$ \\
\hline $20-24$ & 4874 & 6555 & 70.37 & 6255 \\
\hline $25-34$ & 5968 & 9850 & 13018 & 14136 \\
\hline $55-41$ & 5967 & 7159 & 10568 & 13022 \\
\hline $45-54$ & 65.31 & $6+397$ & 7118 & 8899 \\
\hline $.55-64$ & 4153 & 4367 & 5124 & $5 \% 18$ \\
\hline $65+$ & 1056 & 1065 & 1258 & $1+660$ \\
\hline T'otal & 31520 & 39955 & 18725 & 53728 \\
\hline Total & 82715 & 97573 & 112618 & 120600 \\
\hline
\end{tabular}

Source: The actual data for 1970 and 1977 are from Burcau of Labor Statistics, Employment and Earnings. The projected levels are derived by the author. The methodology is discussed in the text and in Michael L. Wachee, "Intermediate Swings in LaborForce Parricipation Rates," Brookings Papers on Economic Actioty, No. 2 (Washington, D.C.. The Brookings Institution, 1977). p1. 545-74. 
Table 2. Compounded Annual Rates of Change for the Civilian Labor Force.

Sex
and
Age $\quad 1970-197 \overline{7} \quad 1977-1985 \quad 1985-1990$

Wale

$\begin{array}{lrrr}16-19 & 3.18 & -0.61 & -0.36 \\ 20-24 & 4.70 & 0.1 .4 & -2.85 \\ 25-3.14 & 4.00 & -.49 & 0.76 \\ 35-44 & 0.21 & 3.77 & 3.94 \\ 45-54 & -0.32 & -0.59 & 2.49 \\ 55-64 & -0.17 & 0.53 & -0.48 \\ 65+ & -2.40 & -0.74 & -1.63 \\ \text { Total } & 1.65 & 1.34 & 0.92\end{array}$

Female

$16-19$

$20-24$

$25-3 \cdot 1$

$35-44$

$45-54$

$55-64$

$65+$

\begin{tabular}{l}
4.01 \\
4.32 \\
7.42 \\
2.62 \\
0.36 \\
0.72 \\
0.12 \\
\hline
\end{tabular}

0.10

0.89

3.55

5.37

0.77

2.02

$\underline{2.10}$
0.46
$-2.33$
1.66
3.68
4.57
1.60
3.11

$\begin{array}{llll}\text { Total } & \underline{3.41} & \underline{2.51} & \underline{1.97} \\ \text { Total } & 2.36 & 1.83 & 1.38\end{array}$

Source: Derived from the data in Table 1.

tion rates by the population figures for each of the age-sex groups. The annualized rates of labor-force growth between 1970 and 1977,1977 and 1985 , and 1985 and 1990 are presented in Table?

The central development projected for the labor markets of the $1980-90$ period is depicted clearly in Table 2. In the 1970-77 period, the labor force grows rapidly for males age 16 to 24 and for females age 16 to 34. This is the result of the passage of the baby boom cohort through that age group and the associated increase in female participation rates. For the 1977 to 1985 period, the baby boom group begins to enter the age 25 to 44 categories with the result that these categories have the largest growth rates. By the 1985 - 90 period, the absolute number of young workers is actually declining for male workers age 16 to 24 and for females age 20 to 24. The major growth occurs for males age 35 to 54 and almost all older female groups.

During the decade of the l980s the num- ber of young workers in the labor force should be declining. The population in the younger age groups will be falling, and their participation rates-as opposed to the unprecedented increases during the 1970swill be largely flat. Comparing the period $1970-77$ with the period 1985 - 90 indicates a demographic transition of immense proportions. The changing outlook for immigration policy is largely a function of this twist in the demographic age structure of the labor force.

\section{Labor Demand Projections}

The 1985 demand projections used in this paper are the official Bureau of Labor Statistics calculations. ${ }^{5}$ They are shown in Table 3. The BLS foresees a continuation of the shift toward white-collar (except sales) and service (except private household) workers and away from blue-collar workers. The largest negative shifts are away from private household workers and farm workers. Since these are two occupations that tend to attract relatively large numbers of illegal aliens, this could signal a slowdown in the demand-pull forces for illegal aliens in the 1980s. I will argue below, however, that these projections may be in error precisely because illegal aliens have already become an important component in these two occupations.

The approach of this paper is to compare the 1985 BLS occupational projections with my labor supply projections for the same year. In adopting this strategy, I label the BLS occupational projections as determined by demand factors and my participation or labor-force projections as determined by supply factors. ${ }^{6}$

\footnotetext{
5See Max Carey, "Revised Occupational Projections to 1985," Monthly Labor Revew, Vol. 99, Vo. 11 (November 1976), pp. 10 - 22 for a detailed summary of the methodology. The approach adopted in this section for projecting age-sex requirements is similar to that used by Arvil V. Adams and Garth Mangum, The Lingering Crisis of Youth Unemployment (Kalamazoo, Mich.: The Upjohn Institute, 1978).

The fact that the BLS constrains total employment in its occupational projections to conform to its own labor supply estimates does not compromise the notion that the model is demand driven. The BLS occupational projections may be viewed as demand oriented because the relative employment by occupa. tion is determined by demand factors with little re-
} 
Table 3. Projected Requirements and Job Openings for Major Occuparional Grotips, 197t io 1985.

\begin{tabular}{|c|c|c|c|}
\hline $\begin{array}{l}\text { Occupational } \\
\text { Group }\end{array}$ & Emptryment & $\begin{array}{l}\text { Projected } \\
1985 \\
\text { Requirements }\end{array}$ & $\begin{array}{l}\text { Percent } \\
\text { Change } \\
\text { (Avernged }\end{array}$ \\
\hline 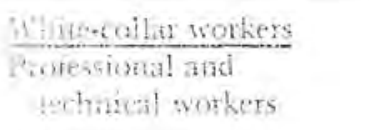 & 12385 & 15.000 & 29.4 \\
\hline $\begin{array}{l}\text { Menagers and } \\
\text { Aministraors }\end{array}$ & $8.9+1$ & 10,900 & 21.6 \\
\hline Gates sorkers & 2,117 & 6.300 & 15.7 \\
\hline Clerical workers & 15.013 & 20.100 & 33.8 \\
\hline Strbtoiat $\left.\right|^{2}$ & 11.799 & $53,2(0)$ & $(27.5)$ \\
\hline 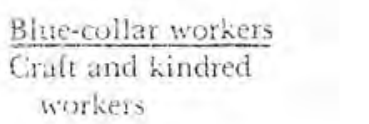 & $11,47 \pi$ & 18,800 & 19.9 \\
\hline $\begin{array}{l}\text { Operatives } \\
\text { Aoniam laborers }\end{array}$ & $\begin{array}{r}13.919 \\
1.380 \\
\end{array}$ & $\begin{array}{r}15,200 \\
4,800 \\
\end{array}$ & $\begin{array}{l}9.0 \\
8.8\end{array}$ \\
\hline Subtotal & 29.776 & 33.700 & $(13.2)$ \\
\hline $\begin{array}{l}\text { Service workers } \\
\text { Private household } \\
\text { workers }\end{array}$ & 1.228 & 900 & -26.7 \\
\hline $\begin{array}{c}\text { Other service } \\
\text { workers }\end{array}$ & 10.145 & 13,700 & 34.7 \\
\hline subtotal & 11,373 & 14,600 & $(28.0)$ \\
\hline Farm wotkers & 3.048 & 1,900 & -39.0 \\
\hline Iotal & 35936 & 10.5 .400 & 20.3 \\
\hline
\end{tabular}

"thetails mav not add to totals because of roundug. Percentages were calculated using unrounded numbers. Source: Max L. Care, "Revised Occupatumat I'mojections to 1985," Monthly Labor Rerview, Vol. 99, No. 11 (Nowember 1976). pp. $10-22$.

In orier to compare the demand an! sup2il) oriented models it is assumed, for demand, that the 1970 age-sex requirements of a job are rigid and, for supply, that the 1970 occupational percentage distribution tor each age-sex group does not change. I hese

gatd to the likely age-sex composition of tix tahot force in 1985. On the other hand, my libor supply jrojections may be viewed as supply oriented because the age-sex composition of the labor force is determined without regard to the demand factors related to the accupational structure.

If the age-sex requirements of an occtparion ate perfectly flexible, there should not be any discrepancy herween the demand and supply projections. Most rescarchers, however, believe that age-sex banters are not pertectly flexible because of such factors as the degree of specific training, job attachmen. socia! assumptions are adopted as expositional, rather than lorecasting, devices because they yield the maximum potential differ. ences between the wo models. The purpose

attudes, and discrimination. Again, the assumption of zero flexibility is adopted for expositional pur. poses and to highlight those areas where supply and demand projections may differ.

it is not correct to assume that iotal age-sex ratios in the demand projections should remain equivalent to the 1970 ratios. Although the 1970 occupational mix is the only input of age-sex groups into the projections, changes in the relative occupation mix will have an sffect on total age-sex ratios. It employment in an industry with a high female concentration increases relative to other industries, then the total male-female ratio will shift in favor of females. What remains constant are the 1970 agc-sex ratios for each occupation. 
Table t. Projections of 1985 Relative Employment by Occupation and Sex. (Percentages) $^{\text {a }}$

\begin{tabular}{|c|c|c|c|c|}
\hline \multirow[b]{2}{*}{ Oinupatron Groutp } & \multicolumn{2}{|c|}{$\begin{array}{c}\text { BLS Ocrupatumal } \\
\text { Domemel ioded } \\
\end{array}$} & \multicolumn{2}{|c|}{$\begin{array}{c}\text { Lubar supply } \\
\text { Indede! }\end{array}$} \\
\hline & Wale & Finglate & Male & Female \\
\hline 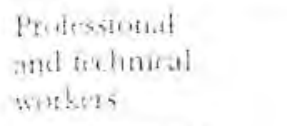 & 9.0 & 6.1 & 8,3 & 7,0 \\
\hline $\begin{array}{l}\text { Aunagers and } \\
\text { admumismarors } \\
\text { execpt tam }\end{array}$ & 0,0 & 1.8 & 6.1 & $1 . \bar{y}$ \\
\hline Sales workers & 3.8 & 2.1 & 3.9 & 3,0 \\
\hline Clerical workers & 5.1 & 14.1 & 4.4 & 15.2 \\
\hline $\begin{array}{l}\text { Craft and } \\
\text { kindred workers }\end{array}$ & 12,5 & 9,6 & 12.0 & 0.8 \\
\hline Operatives & 10.3 & +6 & 11.3 & ii. 1 \\
\hline Nonfarm laborers & 4.2 & 0,3 & $\therefore .8$ & $0 .+$ \\
\hline Service workers & 5.6 & 8.6 & +.5 & $8 . \overline{3}$ \\
\hline $\begin{array}{l}\text { Farmers and } \\
\text { farm laboress }\end{array}$ & 1.6 & 0.2 & 24 & 0.3 \\
\hline Totitl & 612 & 38.8 & 37.1 & 129 \\
\hline
\end{tabular}

"These figures represent percentages of wat employment and habon supply.

Soure, See foomotes 8 and 9.

is to isolate the areas in which discrepancies are likely to arise and analyze the potential "fit" of illegal aliens before market and other foras adjust to equilibrate supplyand demand.

Table 4 presents the 1985 projections, including a sex breakdown by occupation. Columns 1 and 2 indicate the male and fomale ocoupational or demand projections as calculated by the Bureau of Labor Statistics." Columns 3 and 4 indicate the laborforce or supply projections of Iable 1 allocated across occupations. ${ }^{9}$

\footnotetext{
"The sex breakdown for each occupation is robatined by multiplying the BIS demand projection for it by the 1970 proportion of total employment in the occtspation that was accounted for by each of the ltage-sed groups. Total labor demand by sex for each occupation is obramed by summing across the age-sex grotups.

${ }^{9}$ Column 3 indicates the occupational distribution based on the Table 1 age-sex labor-force supply projections tor 1985 . Each of the figures is determined by multiplying the supply projections for each of the 1 it age-sex demographic groups by the 1970 ratios of occupation to total employment for each demograplic group. This vields the projected occupational break-
}

The largest single imbalance is not for minstiled workers, bui for managers and administmators. This is due to the large projected growth of this occupation and an existing age-sex pattern of employment in It that utilizes few women and younger workers. It is likely, however, that females will experience occupational upgrading atd be integrated into managerial positions without much dislocation in any case, this area is rot likely to provide an incentive tor

duwn for each age-sex gromp. Total labor supply for fach oecupation is then obtained by summing over the demographic groups.

In As would be expected. the demand driven model, using 1978 age-sex occupational iequirements, indicates a larger need for male workers than is available from the labor supply projections. Specifically, the BLS occupational mix, projected to 1985, needs a bibor fore that is 61.2 percent male. 1 y labor projections suggest a labor force that is only 57.1 percent male, I do not draw any conclusions trom these sex differences, however, because of the ease of substitut. ing male for lemale workers within an occupation. The major difficulties in stibstituing workers exist across occupations and age groups. 
significant immigration from abroad. The skilled workers who do migrate are a small percentage of the total and tand to be professionals rather than managers.

Comparing the supply estimates with the demand projections of lable 4 for bluecollar trates illustiones the frotential shortage of male crate wontum baberts. and service workers. For exumple, whereas in the

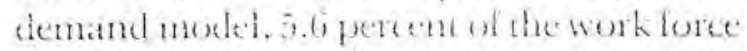
should be mate servige workers, the supply model only provides 1.3 pertent. Adeling io gether the nontarm latorers and service workers-on average the two least-skilled occupations-vields a demand for 9.8 percent male workers and a supply of 8.4 percent; hence a shortall of 1.4 percent. With projected total employment of $107.5 \mathrm{mil}$ lion in 1985, the size of the discrepancy for unskilled males is $1.5 \mathrm{mill}$ ion workers. Since the female supply and demand figures are approximately equal for those two occupations, potential substitution of temale for male workers is not large. Presumably, females could be drawn from higher skilled occupations to fill the shortage: however. this will be limited by the lavorable labor market for females in the more skilled jobs.

Although the numbers from the demand and supply models do not diverge sharply for most occupational groups, significant problems may still energe, frirst, if the number of illegal aliens in an eccupation has been increasing, causing an undermeasurement of employment in it. the BLS may be currendy understating the growth rate for that occupation and understating projected demand for it, ats well. since its demand projections largely assume a continuation of recent rates of growih.

A potential example of this understatement phenomenon appeas in the BLS projections for farm workers and domestic workers. lable 4 shows a significant decline in the relative labor demand for farm labot in 1985. But this is exactly what would be expected if illegal aliens have been taking an increasing percentage of the jobs in an oceupation, because the oecupational projecfions of the BLS are based largely on native employment, In excupations in which itlegal aliens hase already male geantitatively important gains relative to the size of the overall occupation), the projection methodology may seriously understate the gap between the number of jobs and the number of native workers. Furthermore, since the demand projections also understate the future growh of employment in these occupalion?, this gatp (an be expected to grow.

Second. the mamsinton homa a babs boom to a baby betse whon in the younget age groups is only begimsing in the early 1980s. Since the binth rate paked in 1957 and then remained at at high plateau though 1961 , the peak of the bahy boon cohort is still between 24 and 28 year s of age in 1985. The gap between the demand and supply projections shown in Table $t$ should comtinue to widen between 1985 and 1995. Indeed, even the rate at which the gap widens grows until after 1985.

Third, the $16-19$ and $20-24$ ige groups are difficult to evaluate because their laborforce participation rates are particularly sensitive to exogenous changes in school enrollment rates and to the level of the armed forces. My underlying assumptions on these latter two variables are somewhat optimistic in terms of their implications for the likely size of the youth labor force in 1985. This is particularly true given the increasing percentage of youths who are parttime workers. In this sense, the growth in their labor force overstates the growth in their available manhours.

\section{Closing the Shortall}

As shown above, employmen projections based on supply (labor force) and demand (occupation) models indicate a gap or shortfall of the male labor force in the lowest skilled occupations. The size of this gap varies over a largerange depending upon the particular assumptions used in generating the projections. These projections are developed on the assumption of occupational rigidity between male and female workers of different ages.

This occupational rigidity is not an atcenrate description of the labot narket. Rather, the extreme assumption of no occupational adjusment among aye-sex groups is designed to loresee where the ex-ante shortatls in the labor market are likedy to develop. It 
is not designed to lorecast the actual or expost age-sex levels of employment by occupation in the future. This is an important distinction. Since the economy adjusts to shoutalls between supply and demand, projeced diserepancies are unlikely to persist. the fluestom is: What medunism will be atopres! wa whes the supply and demand presintas:

It pesponse in welative wage and prin changes, there atre mumerous market adjustments ihat can yedel a balance between supply and dinand in the labor market of the 1980s without altering the immigration How. These include: a slower growth rate of lower skilled jobs due to changes in the demand for labor; a slower upgrading of the babs bom generation so that more of them are avalable to fill the lower skilled jobs; and clianges in the supply of manhours anong those willing to work in lower skilled markets.

Clearly, occupational employment need not grow along the exponential path predicted by the BLS. Although exogenous shocks could cause departures from the predicted path in cither direction, the endogenous labor market mechanism should systematically push labor supply and demand factors into equilibrium. A favorable endogenous response would likely oecur because any shontage of workers in at particular job would ause firms to substitute against the: scarce input by shifting toward more abundant inpurs. A similar adjustment would be made by consumers, who would shift away Irom relative expensive goods, that is, those that used ielatively greater supplies of the scarce inpute."

"That demographic shifts in stupply can cause large changes in telative wages has been documented tor the experience at the baby boom cohori over the past two decates, See Michial 1. Wacher, "Internediate Swings n I abor-Force Participation Rates," and Finis Weich, "Effects of Cohore Size on Eamings. The Baby Boon Babies Financial Bust." mineo. University al Califormat at Los Angeles. Jameary 1979.

The adjusturents of firms and consumers to changing relative prices and wages woukt not only catuse the BLS occupational assessment to overstate differences with lise atetual labor force but would also result in changes in the occupational inptut matrix. Firms would use retatively increasing numbers of females and ofder males by molding the avaibable workers as fit the demand or by molding the jobs to fit the skills of
In terms of conomie costs, it is always casier to bump workers downward or reduce their promotion than it is to mpgrade them quickly. As a result, the hyouhesied shortitge of entry level workers may te reduced because enough members of the baby hoom cohore will be held back (in entmsof promo(ions) to lill the lower skilled fubs ty pitally

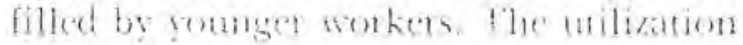

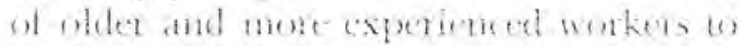
perform unskilled rasks maditionally held by younger and less experienced wothers. however, can have latge social costs bo this group and. perhaps, for society ats a whole.

An important issue in cvaluating the response of the labor market io an influx of illegal aliens relates to the ability of the monetary and fiscal atuthorities to use stimulative policies to create new jobs for the new entrants. It is obvious that when the economy is in a recession an increase in the labor supply due to additional illegal aliens or domestic workers will, ceteris paribus, lead to an increase in the unemployment rate. The cyclical anemployment that exists during a recession can be erased by appropriate monctary and fiscit policies. The more difficult but interesting question is whether the presence of illegal aliens alters the full-employment or equilibrium unemplorment rate.

The type of labor marke model I have adopted suggests that an increase in illegal aliens would not increase the cyclical component of unemployment but would cause the equilibrium unemployment rate to rise. The mechanism, which is explored in greater detail below, is due to the adverse

the workers. Both adjusments are likely to take place with the more malleable fictons absorbing the largest change.

${ }^{13}$ The equilibrium level of unemployment is the level of unemplovment that canno be reduced though general, stmulative monetary and fiscal policies without accelerating intlation. My estimates of the equilibrim rate are derived in "The Changing Grelical Responsiseness of Wage Inllation Ovet the Postwar Period, Brookings Papers on Eronomic Actraty, No. I Washington, D.C. The Brookings Institution, 1976) pp. 115-19. Aiso see Franco Jodigliano and Lucas Papademas, "Farget for Monetary Policy in the Coming Year." Brookmgs Pafers on Ecotomic fotnity, Yo. I (Washington, D.C. The Brookings Institution, 1975). Pp. 141- 13.3 . 
effect of illegal aliens on the market wage of lower skilled workers. To the extent that market wages decline relative to the level of welfare benelits and similar alternatives, the "cost of being unemployed" would therefore be reduced. To the extent that market wages decline telative or minimum wages, or to tmionized wagen in the high-twage sectors, workers would vither be displaced or unemployed herger, atwating a job opening in the high-wage stcur. The result of these adjustments would be an increase in the equilibrium level ot unemployment.

\section{The Distribution of Eenefis and Costs}

The distribution of benefits and costs of illegal aliens. for the native population, depends not upon whether the immigration is legal or illegal but rather upon the demographic characteristics of the immigrants. In this analysis. 1 assume that the great bulk of immigrants are unskilled and are tikely to be employed rather than unemployed or out of the labor force. ${ }^{14}$ My approach is to treat the flow of illegal aliens as equivalent to an increase in the supply of unskilled workers. This view omits important topics including the economic vulnerability of illegal aliens due to their ineligibility for most social welfare programs and a lack of protection under FLSA and collective bargaining statutes. ${ }^{15}$

In theory, the distributional impact of

\footnotetext{
${ }^{14}$ See, for example. Dawid forth and Marion F. Houston, The Chanacteristics and Role of Illegal Aliens in the U.S. Lubor Market: in Explanatory Study, prepared for the Employment and Fraining Administration (Washington, D.C.: L:S. Department of Labor, 1976).

${ }^{15} \mathrm{~F}$ or more general treatment of the economic isstes, see Wayne A. Cornelius, "Illegal Mesican Migration to the United States: A Summary of Recent Research Findings and Policy itmplitutions," mimeo, MIT, 1977; Walter Fogel, "illegal Alien Workers in the United States," Indistrul Relations, Vol. 16. No. 2 (October 1977), pp. 243-63; Michact f. Pinte, "The New Immigration and the Presumptions of Social Policy," in Industrial Relations Resentch Association, Proceedings of the Twenty-Sesenth Annual Winter Meeting, San Francisco, Deccmber 28-29,197t (Janies L. Stern and Barbarat D. Dentris, eds.), Pp. $350-58$ : Edwin P. Reubens, "Polies Dinnensions of the H.2 Program," prepared for the National Commission for Manpower Polios (December 1978): and Vorth and Houston. The Characterstics and Role of lllegal Aliens in the L.S. Labor Market.
}

illegal aliens depends largely on the various elasticities of substitution and scale effects in the production process. If can be argued that, as a rule of thumb, complementary inputs benefit and substitute inputs suffer from immigration. Unfortunately, how. ever, the empirical evidence on which factors of production are complements and which are substitutes is far fron definitive. The iesults depend heavily on the manner in which the inputs ate defined and the number included in the particular production function analysis. Including materials or energy (or both) as inputs, as well as capital and labor, for example, changes the results as to which factors are complements and which are substitutes. It is possible, however, to reach certain tentative conclusions as to the relative magnitudes among inputs. ${ }^{16}$

Given the above qualifications it can be assumed that capital and labor are complements. The strongest complementarity is between capital and skilled workers. The relationship between capital and unskilled labor is closer to the borderline so that any effects are likely to be small. Among different labor groups, workers become increasingly complementary the greater the divergence in skill levels. For example, whereas all unskilled production workers can be classified as substitutes for each other, production and managerial workers are assumed to be complements.

Given this framework, the impact of illcgal aliens, at least in today's labor market, seems indisputable. Although the magni. ude of the effect would vary depending upon the actual number of illegal aliens in this country who are working, the direction of the impact is known. First, illegal aliens depress the wages of the lower skilled native American work force. Second, given existing levels of minimum wages and welfare, for which the Americans but not the aliens are eligible, the wage reduction resulting

${ }^{\text {to }}$ See, for example, F. R. Berndt and D. V. Wood, "Technology, Prices and the Derived Demand for Energy," Review of Economics and Statistics, Vol. 57. No. 3 (August 1975), pp. 259-68 and Errist Berndt, "Reconciling Alternative Estimates of the Elasticity of Substiution." Review of Economics and Statistics. Vol. 58, No. 1 (February 1976), pp. 59-68. 
from illegal immigration may also cause higher unemplosment rates for lower skilled native wrters. This increase in the unemployment rate would be an increase in the equilibrium atic and, therefore, could not be offset by expansionary monetary and liscal policies whihnt fansing arcelerating inflation.

to is sometinte digured in rebuttal that iltegal aliens tatie job that nave Americans wotald not be willity an accept and, hence, that there is lifte on no employment displacement of wage effect. This argument. however, is more romplicated than it appears, as can be seen by differentiating between diree and indirect displacement effects. ${ }^{17}$

In its simplest form, diret displacement means that an illegal al ien accepts a job that is currently beld or would be acceptable to native workers, for expositional purposes, assume that the low-skilled domestic labor force is reluctant to take on steady jobs at or below the minimum wage. Then. jobs held by illegal alicus that pay minimum wages or below would not cause a direct displacement of domestic workers. But, the Immigration and Nattralization Service found in a 1975 survey that 35 percent of the illegal aliens that were apprehended were earning wages above $\$ 2.50$ per hour. This figure was well above the minimum wage. which in 1975 varied from $\$ 1.50$ for farm workers to $\$ 2.10$ tor nontarm workers ${ }^{\text {is }}$

That many jobs otherwise atmactive to American workers are still given to illegal aliens is not surprising. Although these jobs. are "acceptable" to United States citizens, they represent otherwise mattainably high wages to aliens. Auturles are likely to reflect this difference. The illegal alien is an eager and pliant worker, not only because of the fear of deportation but also because the wage is special, not merty acceptable. An employer who does not tiscriminate by race,

"These views were arigindly presented in Michael L. Wachter, "Second Thoughts About Illegal Immigration," Fortune (May 22. 1978), pp. $80-87$.

Hee David North and Allen LeBel. Manpower and Immigration Polictes in the Unted States. A special repont of the National Commission for Manpower Policy, Special Report Vo, 24. February 1978, pp. 137 and 139 sex, or illegal alien status is thus likely to hire numerous illegal aliens for lower skilled johs.

But even if domestic workers refuse to itecept employment because the jobs are matractive and the wages are marginally above public assistance levels. illegal aliems nay cause an indirect displecement effect. To show this, it is usetul io construm a rough hypothetical pionue of the low skilled labor market under the assumption that the illegal alien workers are ferced on reurn to their home countiles tomonom.

In 1978 there were approximately fifteen million full-time equivalent domestic workers who were earning $\$ 3.00$ per hour or less. Assuming an additional six million illegal aliens, that stoup constituted s0 percent of the work force emplosed that year in the lowest skilled labor markets. If all those workers were forced to teave tomorrow and the supply of low wage workers in this country were thereby reduced by 30 percent, wages at the bottom of the job ladder would be driven up significantly. ${ }^{19}$

A further assumption of this scemario is that the supply of "available" domestic workers would increase substantially as wages increased 10 to 20 percent above both the minimum wage of $\$ 2.90$ and the wellare wage for the nonworking poror. This implies an increase in the wage rate of low wage jobs to an average of 5.3 .40 per hour (in constant money terms). With the illegal immigrants out of the competition and with wages at \$3.40 per hour, many domestic workers would now be interested in the previously "menial" jobs.

The next question, however, is how many of these jobs would still be available. Since demand curves for labor slope downward. an increase in wages means fewer jobs. Assuming an clasticity of unity, that is, for every one percent increase in wages, one percent of the jobs are scrapped, approximately 2 million of the 6 million jobs held by the illegal aliens could vanish. The job loss might be even higher if the favorable "attitude" of the aliens were at more impor-

\footnotetext{
These figures were obtained from a tape of umpub. lished data for the May 1978 Current Population Survey.
} 
tant consideration than the wage rate. Hazarding a guess, perhaps another 1.5 million jobs would disappear for this reason. Thus. of the 6 million jobs filled by aliens, approximately 2.5 million would still be open at the higher wages demanded by the domestic low-skilled workers.

Even if these assumptionis anc o!f. it is clem that there would still be potential hat at dramatic improventent in the wages and jobs available to the domestic lither force: This optimistic report on wages and fohs would also translate into a large sedution in the cquilibrium unemployment rate is wages increased, it is likely that more individuals would be drawn into the latbon force. If one-half of the jobs were filled by currently unemployed workers and the other half by new entrants into the labor market, the unemployment rate would still fall by approximately 1.25 percent. This teduction in the unemployment rate is of added significance because it is the fullemployment or equilibrium rate that would be favorably affected.

The economic gains accruing to the lowskilled domestic labor force by sending the illegal aliens back to their home coumtries would be dramatic. The cost, however. would also be high. Perhaps the major cost would be to the aliens themselves and their home countries. Just as wages in the Lnited States would increase. wages in the poor countries of Latin America, especially Nexico, would fall.

Domestically, the repatriation would presumably end numerous service and agricultural jobs and increase the relative prices of the associated consumer products. ${ }^{20}$ Although short-run effects of a sudden departure of illegal aliens might be dramatic, cither a slower departure or the longer-rtin effects of the quick exil could be easily handled. Many of the nonservice jobs could be mechanized and would become new job opportunities for the domestic population. The low-skilled service jobs might well disappear permanently due to the absence of workers willing to take on this em-

\footnotetext{
${ }^{\alpha}$ For simplicity, I assume that only relative wages and prices are forced to adjust. The inflation tate itself is asstumed to be constant.
}

ployment. The economy, lowever, could do without these service functions. Indeed. there is a built-in mechanism that prevents serious disruption: For any job that is "vi. tal," real wages will be bid up in the absence of illegal aliens to ensure the availability of domestic workers.

Perhaps the biggest domestic inmput. trowever. would be the improvenent in dhe status of the low-skilled wotkers relative to both higher skilled workers atnd capital. Since illegal aliens are substitutes for the lower skilled workers but complements to skilled workers, the middle and upper classes might suffer an absolute-as well as relative-decline in income. The relative decline might be significant, but the absolute decline is unlikely to be large enough to cause much discomfort. The exceptions to this, of course, are the skilled workers who work directly with, and the firms that hire, illegal aliens. These individuals and firms would suffer important losses as the wages of the low-skilled workers rose.

In contrasting the labor market of the 1980 s with that of the 1970 s, it appears that the major differences will be a shift from a relative surplus to a relative shortage of lower skilled, entry-level workers. That is, the illegal immigrants would remain a substitute for unskilled workers, but the percentage of native workers who are unskilled will decrease. As a result, the distributional effect of this demographic twist should be similar to the above scenario of a reduction in the number of illegal aliens. Both represent a decline in the percentage and absolute number of young. unskilled workers. But as the baby boom cohort ages, it will shift from a substitute to a complement in terms of its relationship with illegal alicns. That is, by the late 1980 s and 1990s, those labor groups that were most hum by competition from illegal aliens in the 1970 s will have the most to gain from an increase in the number of (unskilled) illegal aliens.

In the battle over income shares among generations or skill groups, the political context may play an important role. In the demographic twist model, the oversized baby boom generation can "outvote" the undersized baby bust cohort. This former group can be expected to search for political 
solutions to its problems. They may vote to prevent either actual shortages of unskilled workers from developing or important relative wage adjustments fom occurring. One approach to attain their objectives would be to vote for a more liberal immigration policy, legalizing and moreasing ienday s llow of illegal immigranes and allowing themi of lecome permanem rei(tentis.

\section{Policy Dilemmas}

Immigration policy has historically posed a signilicant dilemma the to the uneven distributional impace on tifferent income classes. As indicated above, skilled workers tend to gain from increased inmigration while unskilled workers hose. But while immigration has negative effects on the domestic lower income groups, it has strong benefits for the even lower income groups from neighboring foreign countrie's.

One aspect of this distributional dilemma that has not received sufficient attention is that, due to differential birth rates, the new entrant baby bust cohort of the 1980)s will have a much higher percentage of minomity workers than the current cohort. If taced bs continuing pre-labor market discrmination that reduces their market skills. these workers may be hard pressed to face the competition of a large influx of low-skilled immigrants who are eager to work at or below United States minimum wage standards. Faced with a tight labor market for young unskilled workers, however, the disadvantaged workers over the I980) mav be able to make important gains. These potential gains would be blunted by legalizing and increasing the flow of foreign wotkers.

In discussing policy options thee tepresentalive types cau be identilied inereasing the llow of legal immigration in an atemp! to reduce the illegal component; adopting a "guest worker" approach similar to that used in Europe; or continumg the more laissez-lane "nonipolicy" that is cumently in eflect. ${ }^{21}$ The lack of interest in dealing with

\footnotetext{
${ }^{21}$ Major policy innovations in the immigratwon anea are not currently populat in Washingtom or underel, elsewhere in the country. That such metsures ate
}

the immigration question is in part a reflection of the significant political dilemma posed by this problem. But with the onset of the demographic urist in the 1980s, it will be increasingly diflicult to avoid a conscions polic: to control the number of new immi. grants

Fon mumerous political and moral reasons. there is much to be sad for atlowing ai moreased llow of legal immigrans, the the approseh deals with the problems of the potential shortage by atugmenting the baby bust cohore with immigrants, but it has sone significant problems. Already menlioned is the notion that any increase in intmigration would have adverse distributional effects for the domestic low-income. workers. In addition, there are reasons (n) believe that such a policy would not reduce the demand for illegal aliens. If new immigrants had the same welfare benelits as native workers, their work pattern might change and become similar to that of the native unskilled population. Presumably, their labor-fore participation rates would then decline and they might be as unwilling to work in those "bottom rung" jobs as are native workers. The resule would be renewed interest in illegal aliens who would be willing to work at the jobs that were unattractive to legal immigrants.

Due to opposition to both the status que and increases in the annual guota of author-

now anpopular, lowever. onls provides information on the current polutical vitws of the native population toward illegal atiens. That is, the illegat aliens are not perceived as being a "threat" that woukd necessitate the development of a stricter policy or prevent illegal entry. If the enwronment changes, and illegal aliens are perceived as posing a threat to the voting poputition in the Unied States, an enforcenent mechanism could be developed. A policy to restria illegat immigration would likely be composed of three elements: a requirement that workers be able to prove their ritizenship by carring working papers on a "work eligibility card": costly economic penalies assessed against emplovers who hice illegal aliens; and at strengthening of the policing function of the $\mathrm{mm}$. gration and Naturalication Servict.

eqthe political and morat issues are stressed by Wayne A Comelius, "Hegal Dexican Migration io the United States"; Michaed J. Piore, "The New lut migration and the Presumptions of Social Policy": and Bruno Stein, "Immigration as at Social isste." in IRRA, Proceedengs of the 7 wenty-Setenth Amual Hinter Meeting. p). $341-13$. 
ized immigrants, numerous variants of a "guest worker" policy have been suggested. Such a program would have greater flexibility than altemative programs since, in theory, the stock of guest workers can be adjusted, of some extent, in either direcfion."- Dhis is particularly important wh respect to the atrerse impact of increased inmigration on the econonic gains of disadvantaged hative workers. In addition, the avaibibilitr of a "guest worker "policy is likeiy to make it much easier to enforce the laws againsi illegat aliens. The guest workers would satisty the need (whether valid or not) of (mployers for an assured low-wage

\footnotetext{
${ }^{23}$ But see the Mirtin and Miller article in this symposium tor at discussion of the generally unfavorable expcrience of Western European nations in adjusting their stocks of guest workers.
}

labor force in areas stich as agriculture. If there were no pull from employers within the Inited States, the llow of illegal aliens would be likely to decline significantly.

The guest worker approach raises important social and political questions due to the aneigal rights acorded these workers. Alihongh guest workers would prestmably tec oweted by minmmon wages, they would non ite eligible for many social wellare programs. esperially those that affect the "cost of being unemployed." Indeed, the basis for the guest-worker approat h is that individ. uals (and their families) remain in the thited States only as long as they are working or actively searching for work. It is precisely this status incquality that provides protection to the native work force and makes guest workers an alternative to illegal immigration. 